\title{
Vitality of Village UMKM in The Arena of ASEAN Economic Community
}

\author{
DHANNY SEPTIMAWAN SUTOPO \\ Department Sociology, Brawijaya University \\ email: sutopo_dhanny@ub.ac.id, or sutopo_dhanny@yahoo.co.id
}

\begin{abstract}
Due to their meeting commitment of integration. The culmination of the regional cooperation commitment in Southeast Asia is an agreement to become a solid community within the framework of the Asean Community. One aim of the Asean Community is to form a joint economic community among the countries in Southeast Asia, commonly known as the Asean Economic Community (AEC). AEC opens space for the flow of goods and services from ASEAN member countries freely, including items that have been developed by Usaha Mikro Kecil dan Menengah (UMKM) - Micro Small and Medium Enterprises. The implementation of AEC will slowly and surely give implications to UMKM and regional economy, more specifically the areas with less attention preparing for UMKM to face the Southeast Asian regional free market. This research will conduct a preliminary assessment towards the local government's innovation in facing the implementation of AEC, primarily that relates to organizing UMKM at the local/village level. The purpose of this study is to gain an understanding in greater detail in accordance with the local government's response and strategies in Malang Raya to prepare village UMKM in dealing with the implementation of AEC. The study also attempts to find the initial design of strengthening the village UMKM that is adaptive to current regional and global trade liberalization. Field research will be conducted in Malang Regencies, Malang City, and Batu City, where all these areas have village UMKM that are sufficient to contribute to the local economy.
\end{abstract}

Keywords: regional economic cooperation, Asean Economic Community, Village UMKM

\section{Introduction}

In contrast to the early history of the establishment of ASEAN which was very strong with its political overtones, ASEAN today concerns with strengthening regional integration in economic issues. Economic regional integration in Southeast Asia was marked by the agreement to be one common economic area, known as the Asean Economic Community (AEC). AEC is designed to confront regional and global economic challenges for countries that are members of ASEAN, Secretary Directorate General of ASEAN Cooperation (2010: i).

AEC was initiated in the ASEAN Charter at the 13th ASEAN Summit in Singapore, November 20, 2007. As a regional cooperation, which was signed and ratified, AEC is obliged to run. The Government of Indonesia as a member of ASEAN is optimistic about this
AEC. It is indicated from the opening speech by the President of Indonesia Joko Widodo in National Discussion XV of HIPMI (Association of Young Entrepreneurs of Indonesia) 2015 that was held in Bandung 11 to 13 January 2015. In his speech, the President Joko Widodo (2015) said that Indonesia was the most feared among the other ASEAN countries as Indonesia has the potential of human resources with a greater number of entrepreneurs than the other ASEAN countries.

The optimism of Indonesian government related to the implementation of AEC only views at some sides and ignore the other sides. Human Resources of Indonesia today is at a favorable position. About $70 \%$ of Indonesia's population is at productive age. The data of Badan Pusat Statistik (Central Statistics Agency) in 2004 to 2013 showed

Received: August18, 2016, Revision: November 01, 2016, Accepted: December 19, 2016

Print ISSN: 0215-8175; Online ISSN: 2303-2499. Copyright@2016. Published by Pusat Penerbitan Universitas (P2U) LPPM Unisba Accredited by DIKTI. SK Kemendikbud, No.040/P/2014, valid 18-02-2014 until 18-02-2019 
that Indonesia had productive age as much as 121.19 million workers, Badan Pusat Statistik (2015) . However, there is a question raised whether the Indonesia's abundant human resources have been completely prepared for the regional cooperation in the economic field which is based on the footing of the free market and free competition?

The lack of attention to strengthening the human resources in the face of regional economic integration within AEC framework triggers fears of unpreparedness in other sectors, not only in the policy but also institutional level. One of them is related to UMKM. An important point of the AEC is the creation of free market and the flow of production in the ASEAN region. Goods (the result of economic activity) may be traded freely across the ASEAN regions. Obstacles to the entry of imported goods, either through the mechanism of tariff and nontariff is set to be minimized, even charged duty-free. Consequently, all producers of goods produced by UMKM sector to the large corporate sector must be ready to compete when the AEC is effectively implemented.

Free-enter and free-compete goods in a region include goods produced from UMKM sector in the form of handicrafts, food processing, furniture, and ceramic. When some of the industries have been developed by UMKM must compete freely, the declining potential of UMKM due to the implementation of regional cooperation in AEC would be very likely to occur. Initial analyses of the similar kind of cooperation, which is ASEAN China Free Trade Area (ACFTA), shows that there are inaccuracies between the inflow of industrial goods from China to Indonesia and the outflow of industrial goods of UMKM from Indonesia to China. The condition is further aggravated when the number of Chinese imports rise into commodities developed by UMKM in Indonesia, Indotextiles (2012). Malang region, which consists of Malang Regency, Malang City, and Batu City, is an area which has considerable numbers of UMKM sector. The types of UMKM in the three areas in Malang are very diverse, starting from the food processing industry, textiles and clothing, wood crafts, food and drinks made from local materials, furniture, ceramics, to local fruit processing. The existing attractions in Malang that have become local and foreign tourists' destination also contribute to support the development and diversity of the growing industry.
The existing potential of UMKM in three regions in Malang Raya is a positive thing. AEC provide an opportunity for UMKM in those regions in Malang to participate in taking the positive influence of the implementation of AEC. However, there are some things that allow UMKM in Malang to have difficulty in competing with one another. One of the related factors is the issue of patents. Many UMKM dealers in Malang Raya do not understand the issue of patents for their production very well. Preliminary data shows that UMKM in Malang, Malang Raya (2009), particularly in the Batu City, had minimal knowledge and awareness about patents to avoid being imitated by the outside community.

Another problem faced by UMKM is associated with the standardization of UMKM products, capital, and its main market access of export. The products of UMKM in the same type and that carry the identity of Malang do not have an equal quality. One example is Kripik Tempe Malang. It is very easy to find many stores selling Kripik Tempe in Malang that each of those products do not present any difference. This typical condition represents a real picture about the lack of people's knowledge and comprehension on the patent. If the issue is not handled properly, it is very likely to find the same product in multiple places of business.

Another thing that does not lose the complexity faced by UMKM is the access to foreign markets. Although some UMKM have been able to expand its market abroad, but there are more UMKM in Malang Raya that meet a problem in expanding overseas markets. Limitations in the knowledge of export mechanism, weaknesses in the mastery of information technology, as well as the lack of information on the situation of overseas markets have been some hinders faced by UMKM in Malang.

The present study focuses on the performance of local governments in preparing for UMKM in the region to meet the implementation of the AEC, especially the local governments in Malang Regency, Malang City and Batu City. Regional integration within the framework of AEC greatly affects the survival and development of local UMKM. The role of regional government in promoting the survival and development of UMKM is very prominent when some important structural issues related to market access, technology mastery, and capital occur at any time. The local government should ideally be able to 
bridge the increasing competitiveness of UMKM in the region so they remain survive and are even be able to optimize the opportunities that accompany the implementation of AEC. Moreover, it will be great if UMKM strongly supports the acquisition of Pendapatan Asli Daerah (local revenue) in Malang Regency, Batu City, and Malang City.

In this study, the UMKM surveyed are those that are in the village/district in Malang Regency, Malang City, and Batu City. The background of selecting UMKM in those areas is the present tendency of creating territorybased cluster industry and the village position that is considered to be central of economic activity for the villagers as a consequence of the implementation of the Law of Village. This focus will provide further benefit from this research that is getting early feedback related to the design of rural economic development with the basis of UMKM in the near future time.

\section{Research method}

This study is conducted by utilizing a qualitative method that is appropriate to the research objectives and the nature of the research object. The qualitative method allows researchers to analyze the structure, behavior, and social actions to answer the research questions through a deep comprehension of social facts (Moleong, 1985). Thus, researchers will be helped in understanding the context of the problem accurately to build a generalization of the subject of the study (Moleong, 1985).

\section{Result and discussion}

With the challenges of the implementation of decentralization, in 2015 all local governments have to face the consequences of the agreement on regional economic cooperation within the framework of AEC. The local government is required to not only look at the internal problems but also respond the external challenges. The effective implementation of AEC will be carried out at the end of 2015 and it will obviously provide a challenge for the associated regions with their ability to prepare the local economic potentials to have a free competition with the economic actors of Southeast Asia. The potentials of UMKM that are growing in local region and positively contributing to the economic foundation of the region will deal with challenges in maintaining and developing their ability when the competitors from outside area aim to dominate the markets in ASEAN countries. Innovation and state facilities are one of the things that provide a strong foundation for the survival and development of UMKM in the ASEAN free market era.

\section{ASEAN Economic Community}

ASEAN Economic Community or AEC is the realization of 2020's vision which is the ASEAN's efforts to deepen and broaden economic integration in Southeast Asia. AEC is expected to boost up open principles and outward-looking, and to encourage multilateral economic rules. AEC will shape ASEAN as a single market and a single production base that aims at accelerating regional integration in various prioritized activities, facilitating the movement of entrepreneurs and talented employees, and strengthening institutional mechanisms of ASEAN. With AEC, ASEAN is expected to grow more dynamically and competitively in facing the challenges from inside and outside of the regions, Secretary Directorate General of ASEAN Cooperation (2008: 5-6).

\section{Table 1 \\ UMKM Segment of Exports ( $\%$ from total export)in developing countries in Asia 1990-2010}

\begin{tabular}{|l|l|}
\hline Countries & Average Segments \\
\hline Thailand & $10-40$ \\
\hline Philippines & $20-25$ \\
\hline Vietnam & 20 \\
\hline Indonesia & $20 *$ \\
\hline Singapore & 16 \\
\hline Malaysia & $10-15$ \\
\hline $\begin{array}{l}*: \text { only in manufacture } \\
\text { industry }\end{array}$ & \\
\hline
\end{tabular}

Source: Masyarakat Ekonomi ASEAN 2015: Peluang Dan Tantangan Bagi UKM Indonesia(ASEAN Economic Community 2015: Opportunities and Challenges for UMKM in Indonesia), page 13.

AEC have gradually followed a series of economic integration with an ideal goal to establish a common market for the products of member countries of ASEAN. In addition, the products of UMKM will experience the consequences of the opening of ASEAN market. The UMKM that is already prepared for this will pleasurably welcome the implementation of AEC because it will make the regional market easier to develop. Meanwhile, the other UMKM that is not ready will possibly 
worry about the expansion of other products from across countries and actors. According to Tulus Tambunan T.H in his article entitled Masyarakat Ekonomi ASEAN 2015: Peluang dan Tantangan Bagi UMKM Indonesia(ASEAN Economic Community 2015: Opportunities and Challenges for UMKM in Indonesia). The enactment of AEC may affects UMKM in Indonesia, because the quality of Indonesian UMKM is not comparable with other UMKM from other countries, Tambunan (2013). Most Indonesian UMKM's exports are derived from the manufacturing industry and even then the number of exports is still too far in comparison with the large businesses in Indonesia. Compared with UMKM in other ASEAN countries, the export of Indonesian UMKM is still unmatched for the other ASEAN countries.

In addition to the less attention to the quality of goods, the competitiveness problem of UMKM products in Indonesia compared to products by the large industries and UMKM in other countries also become a weakness that should be a concern of many parties. Several countries in Southeast Asia have a better level of competitiveness compared to Indonesia. Moreover, when compared to global level, the developed countries have a more advanced level of competitiveness than what is currently achieved by UMKM in Indonesia (see chart). This will give a reflection for the Indonesian government, especially the Ministry of Industry and Trade that is also responsible for promoting UMKM industry in Indonesia.

Table 2

\section{Competitiveness of UMKM} in Some Countries/APEC

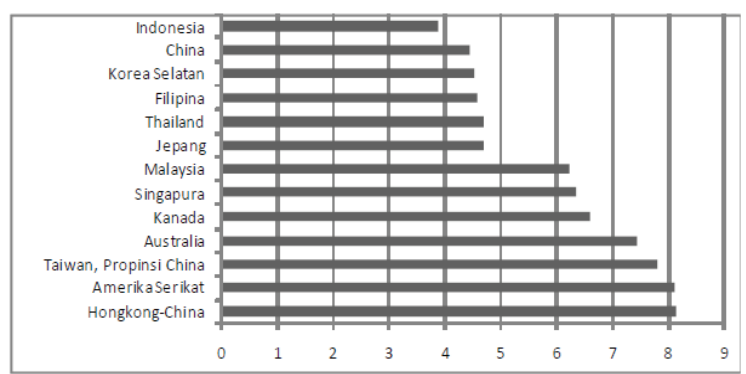

Source: APEC (2006a,b)

It can be seen from the graph above that the competitiveness of UMKM in Indonesia is still less than the other ASEAN countries, such as the Philippines, Thailand, Malaysia and Singapore. In addition, Indonesia is also noted as being the least that provides funding for technological development that is on the scale of 3.5 out of 10 , whereas technological development is an important factor in increasing the level of competitiveness.

The presence of AEC actually provides both opportunities and constraints for UMKM in Indonesia. If only the UMKM in Indonesia can improve the competitiveness with the other UMKM of ASEAN countries, the UMKM of Indonesia will greatly benefit from the implementation of AEC. However, the constraints of AEC should also be considered, such as limited working capital and investment, difficulties in marketing, distribution and procurement of raw materials and other inputs, limited access to information about market opportunities, limited workers with good skills (low quality of human resources) and technological capabilities, transport costs and high energy; limited communications, high costs of complex administrative procedures and bureaucracy, especially in obtaining a business license, and the uncertainty as a result of the unclear economic regulations and policies.

\section{Micro Small and Medium Enterprises (Usaha Mikro Kecil Menengah)}

According to the definition by Law No. 20, 2008 on Usaha Mikro, Kecil dan Menengah (UMKM), Microenterprise is a productive enterprise that belongs to individuals and/or individual businesses with the criteria of asset maximum of 50 million and a maximum turnover of 300 million, Departemen Koperasi (2015).

Small business is a productive economic activity that stands alone and is carried out by an individual or a business entity that is not a subsidiary or branch of the company that is owned, controlled, or a part of the medium or large business either directly or indirectly. A criterion for small business is a business that has assets of 50 to 500 million and a turnover of 300 million to 2.5 billion.

Meanwhile, medium enterprise is a productive economic enterprise that standalone and carried out by an individual or business entity that is not subsidiaries or branches of the companies owned, controlled, or be a part of small or large businesses either directly or indirectly with total net assets or annual sales revenue is up to 500 to 10 billion and turnover of 2.5 to 50 billion.

In the development, the study of UMKM is getting more attention for observation along with the significant 
change of work patterns of industries in the world. Flexible Specialization has become a new pattern of economic development where the advancement of technology, communication, and transportation makes economic scale not very important and instead it is possible for small factories to be more efficient in stimulating the achievement of economic results, Piore and Sabel (1984) . The presence of industry in UMKM scale is a follow-up phenomenon of the economic model of efficiency as developed by the concept of Flexible specialization.

\section{Usaha Mikro Kecil Menengah (UMKM) in Malang}

In Malang, there are many UMKM from various sectors that create employment and also contribute to the improvement of the local economy in each region, the following is the description:

\section{Malang City}

Malang is potential in various sectors which can be cultivated and used by the community. In the agricultural sector, Malang has corn, sweet potato, and cassava as the winning potential. The sector of the plantation produces sugar cane, coffee, coconut, cashew, and cotton. In the livestock sector, there are cows, pigs, sheep, goats, buffaloes and horses, BKPM (2013) . Of the sectors which have these potentials in Malang City, many of them are reprocessed or recycled into new products by the local UMKM, such diversity can be seen from the diagram below:

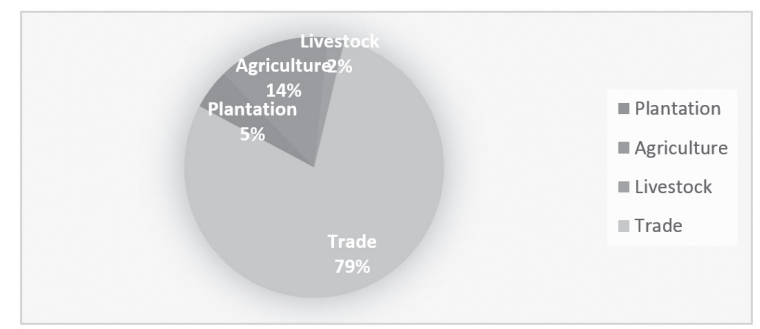

Figure 1.Cooperative Business Diversity Malang per 30 September 2015

Source: Cooperatives Service of UMKM, Keragaman Sektor RiillReal Sector Diversity),http://diskopumkm.jatimprov.go.id/ download.php?id=19accessed on June 19, 2015

Viewed from the above data, the trade sector dominates the UMKM in Malang, followed by agriculture, plantations and livestock sectors. The types of excellent products of UMKM in Malang include tempeh chips, assorted crafts, clothing, agates, and a variety of culinary products, Dinas Kominfo Kota Malang (2015). Some products of UMKM Malang have penetrated the national and international markets, such as tempe chips, processed drinks, candies, seaweed and basket and jar crafts, Dinas Kominfo Kota Malang (2015).

The number of UMKM in Malang in 2011 was 500 units of which 120 units have joined the community and 20 percent of all UMKM in the city is still new in this field, Kementerian Koperasi dan Usaha Kecil Menengah (2011), this number is expected to increase in 2014 in which there are a thousand units of UMKM, but only 200 units are registered in the community, Malang Post (2014) .

\section{Malang Regency}

In topography, Malang regency consists of mountains, highlands, lowlands, and coastal regions. The average air temperature is between $19,1^{\circ} \mathrm{C}$ to $26,6^{\circ} \mathrm{C}$. With this type of topography, Malang becomes fertile and has a lot of natural potentials, Pemerintah Kabupaten Malang (2011) . In agriculture, Malang regency produces corn, soybeans, sweet potatoes, and cassava. Plantations produce cocoa, rubber, sugar cane, coffee, coconut, cloves, cashew, cotton, tea, and tobacco. Livestock sector produces cattle, sheep, pigs, goats, buffaloes, and horses, Pemerintah Kabupaten Malang (2011). While in the field of fisheries, sea fishing production includes tuna, freshwater production is tilapia, catfish, and carp. In addition, brackish water produces shrimp, Dinas Kelautan dan Perikanan Kabupaten Malang (2015) - Apart from the natural products, the tourism sector of Malang is also something to appreciate, ranging from mountains, beaches, waterfalls, plantations, and dams. There are also archaeological travel destination such temples, stupas, and statues.

As previously discussed above, the potential of Malang regency lies mostly on natural resources or the primary sector. The economic sector which is supported by the primary sector has the disadvantage of the low added value that results to the relatively low selling price. Therefore, the economic contribution of the industrial sector is shifted toward the processing industry sectors (agro-industry and mining). The sectors that contribute to economic growth is the construction, trade, hotels, restaurants, agriculture, and processing industry sectors. 
The shift encourages the creation of UMKM that utilizes these potentials into refined products such as food or crafts. The number of UMKM in Malang regency in 2012 was as many as 273.091 units spread out in various sectors, Antara Jawa Timur (2015).

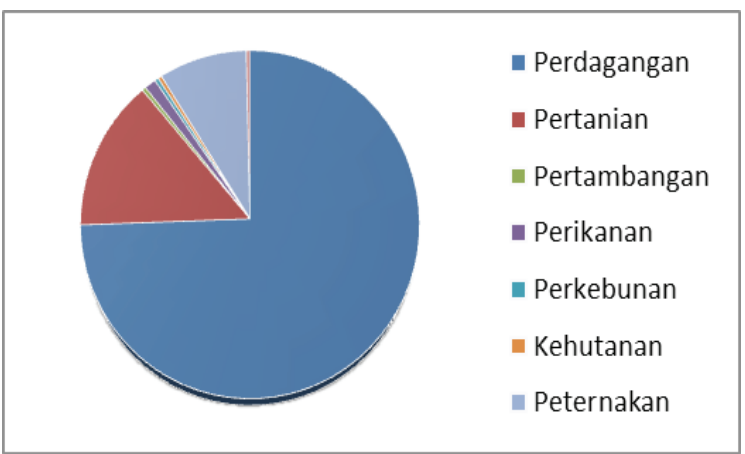

Figure 2. Cooperative Business Diversity in Malang Regency per 30 September 2014

Source: Cooperatives Service of UMKM, East Java KeragamanSektorRiil(Real Sector Diversity),http://diskopumkm.jatimprov.go.id/ download. php?id=19 accessed on June 19, 2015

As may be viewed from the above chart/ graph above, the highest sector of UMKM cooperatives trade sector with the number of 198 units, followed by the agricultural sector with the number of 38 units, sector dairy farm with 21 units, the sector of beef cattle farms as many as 1 unit, the livestock sector goat with 1 unit, then the fisheries sector, that is marine fisheries, as many as one unit. The presence of UMKM has also contributed to the improvement of the economy in Malang regency. One example of UMKM contributions in improving the economy in Malang regency is the present growth of cooperatives in Malang which reach more than 1.5 trillion of assets in 2014, Seputar UKM (2014) , and UMKM also absorbs the labor force as many as 469.274, Antara Jawa Timur (2015) workers so it indirectly also contributes to the improvement of labor'swage standards in Malang which can be seen from the table below.

The chart above shows that over the years the standard wage in Malang regency has increased, in 2011 the standard wage was Rp1,077,600 and in 2015 increased to Rp $1,962,000$. Thus, the presence of UMKM has improved the society welfare and also brings an impact on the economy of Malang regency which can be seen from the growth of Pendapatan Domestik Regional Bruto (PDRB).

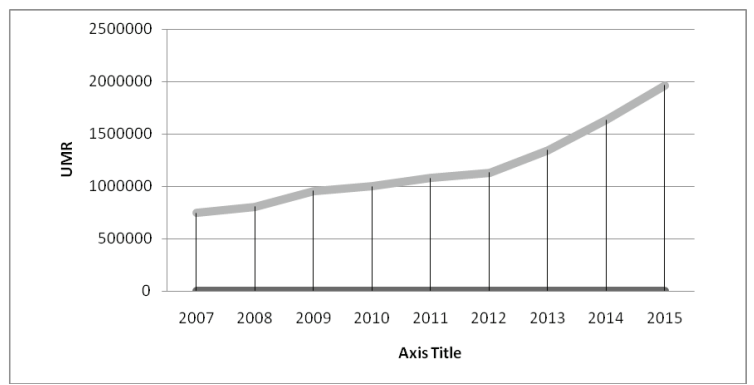

Figure 3. Upah Minimum Regional (UMR) regional minimum wage in Malang Regency $2007-2015$

Source: Compiled from various sources

The contribution of UMKM can also be seen from the increase in PDRB of Malang regency which continued to increase from 2006 to 2012. In 2006 the GDP of Malang regency was $R p 16,786,416$, in 2007 was $12,325,207, \mathrm{Rp} 13,035,088$ in $2008, \mathrm{Rp}$ $14,542,303$ in 2009, Rp 14,578,968 in 2010, Rp 15,624,097 in 2011 and in 2012 amounted to $\operatorname{Rp} 16,786,416$. These figures show that Malang regency is one of regencies in East Java province which has a high level of economic activity. In 2006 to 2012 the PDRB of Malang regency continued to increase and ranked the top 5 in 2005-2010, Regulations by the Regent of Malang (2011: 25).

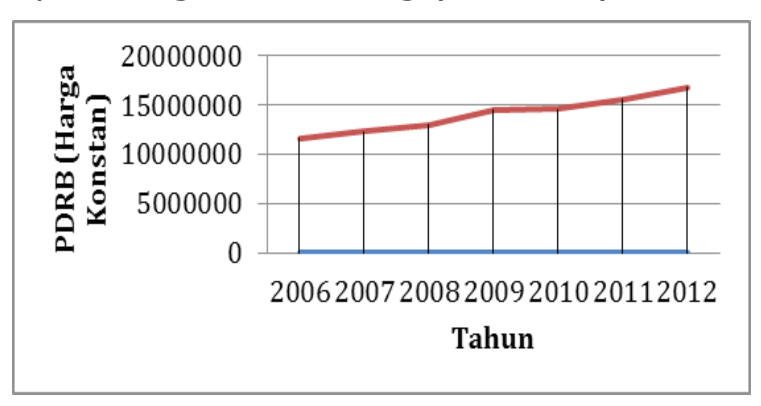

Figure 4. Pendapatan Domestik Regional Bruto (PDRB) - Gross Domestic Product Constant Price Malang Regency, 2006-2012

Source: Compiled from various sources

\section{Batu City}

Batu City has a high landscape that is suitable for agriculture and plantations. The main commodities in the agricultural sector crops are rice, peanut, corn, sweet potato, cassava, and soybeans. Fruit production includes avocado, apples, and durian, while the plantation sector produces sugar cane and coffee. In addition to the agricultural and plantation sectors, Batu City is also famous for its ranch, namely dairy cows, beef cattle, goats, sheep, goats, and laying hens. As a tourism center, Batu city is famous 
for its natural, cultural, and artificial travel destinations, so it encourages the trading sector of the city, Government of Batu City, (2013) .

The potential of nature and landscapes have promoted the diversity of UMKM in Batu city. The number of UMKM in Batu city in 2003 has reached 14,570 units located in various sectors, Fauzi (2013). The most contributing sectors trade, then agriculture, livestock, mining, and industry follow sequentially.

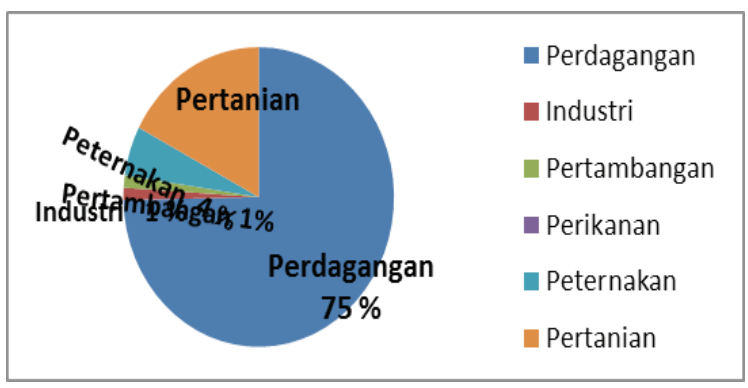

Figure 5. Cooperative Business Diversity in Batu City per 30 September 2014

Source: Cooperatives Service of UMKM, East Java, Keragaman Sektor Riil,http://diskopumkm. jatimprov.go.id/download.php?id=19 accessed on June 19, 2015

The featured production UMKM in Batu includes processed foods and beverages made from apples, Pujon cow's milk, mushrooms and various wooden crafts, Editor Malang Raya (2009). The presence of UMKM in Batu is also contributing to the economic growth as seen from the PDRB and UMK in Batu where this can positively impact people's lives, Hapsari (2014).

It is important to disseminate the socialization of businesses related to the potential brought in the implementation of MEA for the UMKM in order to change their mindset and orientation of the UMKM. Since MEA is seen as a threat rather than as an opportunity for UMKM, it results to the lack of preparation for some UMKM that may not be aware of the benefit of MEA as a crucial instrument for the expansion of UMKM in a whole area of Malang. Therefore, in the view of the Department of Industry of Malang City and Malang Regency, socialization on UMKM becomes an urgent agenda to be given to all UMKM organizers.

The next strategy undertaken by the three governments in Malang is upgrading the quality of UMKM products. This strategy is implemented through a series of training and facilitation for UMKM in order to improve the UMKM product quality. There are various types of training that are facilitated by the local government. Packaging training, business management training, training development of quality products, and market development training are a series of training organized by the local government for UMKM. In upgrading the quality of UMKM products, Malang government also provides on-demand training, that is a type of training based on the proposal/demand by UMKM in relation to their needs of assistance through the training.

To overcome the problem of the limited market for UMKM products in Malang, the local governments commit on an intervention by including UMKM products in any UMKM products exhibitions organized at the national, Southeast Asia regional,and international levels. At least since 2013, especially in Malang city and Malang regency, there had been facilitation programs for UMKM business people to take part in UMKM product exhibitions, both at the national, regional, and international levels. At this point, compared to the other two regional administrations in Malang, it can be said that Malang city has provided a broader market for UMKM products in regional and international level. In Malang regency, the market facilitation has been focused on domestic markets of East Java and on the national scale.

In addition to the governments' facilitations for UMKM, Malang city government is also working on the development and expansion of the market for UMKM products to the Africa. Based on the assessment of the Industry and Trade Service of Malang city, the African market is very potential for the expansion of UMKM exports. The assessment with the government of South Africa, especially with the South African Ambassador, showed considerable opportunities for market expansion into the African region. With the relatively easy requirements for UMKM, compared to the expansion to the European markets, the choice of market development to African region into is considered as a prospective move.

The next strategy performed by the government in Malang is to facilitate the business licenses for UMKM business agents. As generally known, there have been some UMKM that do not administer for their licenses due to not knowing the procedure, worried over if the license fees are expensive, as well as fears of the consequences after the 
business license issued. To overcome this, the local government in Malang, particularly Malang city, attempts to simplify the licensing making process. In fact, to make the UMKM more aware of business licenses, Malang city government even eliminate the license fees.

In connection with the capital matter, the local governments in Malang regency, especially the Department of Cooperatives, provide capital access for UMKM that expect to develop their business. In coordination with the central government, the access to capital for UMKM, particularly micro and small businesses, is provided with a low-interest rate, compared to the interest of conventional banks. The access to conventional/general banking capital can also be done once the UMKM business license is out. Thus, the simplification of the licensing process and the free charge provided by the local government is also very helpful in opening and expanding the UMKM access to capital.

The next strategy developed by the regional government in Malang is to set regulations that support the growth of UMKM. One regulative effort is the draft of local regulations on Franchise, in which each franchise will be required to provide access to UMKM products for sale in all franchises operating in Malang. This strategy is designed under a consideration that without any affirmative action that gives access to UMKM, the franchises would not have concern for the local UMKM products and instead would very conveniently incorporate the export products from other countries in Southeast Asia.

\section{Conclusions}

The readiness of local governments in making UMKM as a superior performer in Southeast Asia regional economic cooperation has been carried out comprehensively. There have been solutions to any problems in relation to the success of the cooperation. This readiness is also a good starting point, it indicates that MEA at a certain point opens wide opportunities for any business agents to be ready to compete at the regional level,to develop markets, and also to test the vitality of UMKM. In order to prepare UMKM Malang to be able to compete with products of other Southeast Asian countries along with the opening of ASEAN, the local government has conducted a series of facilitating programs for UMKM in Malang. The cooperation with the central and provincial governments has also been implemented by the local governments with the aim to develop the UMKM in the whole area in Malang. The series of activities encompassing product promotion through taking part in any regional product exhibitions, training for the improvement of product quality and human resources, and provision of facilities in the access to capital have been implemented by the local governments of Malang. However, there is an impression that the attempts of local governments in preparing UMKM Malang to compete in MEA are quite late to be done, with regards to the increasing intense activities that have just been started in 2013.

Additionally, the above conditions are worsened with the specific characteristics of the majority of UMKM in Malang, namely their sense of inferiority, fears of doing a market expansion for their products, and orientation to the local market as the basis for their development of UMKM. The aforementioned characteristic of UMKM Malang can not certainly be separated from the lateness and weakness factors of local governments in preparing UMKM to have regional and even international insights. In fact, the government, both central, provincial, and regional, has more than 10 years since the Bali Concord II in 2003 which became the embryo of a commitment to regional market integration in Southeast Asia. The lack of coordination and cooperation between the different levels of government has become a trigger point from the late actions taken by the governments to prepare UMKM for MEA.

\section{References}

Antara Jawa Timur. (2015). Serap 469.274 Tenaga Kerja, UMKM Kab Malang Maju Pesat. (http://www.antarajatim.com/ lihat/berita/103472/umkm-kabupatenmalang-serap-469274-tenaga-kerja) accessed on June18, 2015.

Badan Pusat Statistik. (2015). Jumlah Angkatan Kerja, Penduduk Bekerja, Pengangguran, TPAK dan TPT, 1986-2013. (http://www.bps.go.id/linkTabelStatis/ view/id/973) accessed on May 7, 2015.

BKPM. (2013). Komoditi Unggulan Daerah (Local Commodity). (http:// regionalinvestment.bkpm.go.id/newsipid/ area.php?ia $=3573$ ) accessed on June 18 , 2015.

Departemen Koperasi. (2008). Usaha Mikro, Kecil Dan Menengah (UMKM). (http://www.depkop.go.id/attachments/ 
article/129/259_KRITERIA_UU_UMKM_ Nomor_20_Tahun_2008.pdf) accessed on May 7, 2015

Dinas Kelautan dan Perikanan Kabupaten Malang. (2015). Laporan Kinerja Tahun 2014.

Dinas Kominfo Kota Malang. (2015). Berbagai Produk Unggulan Daerah Dipamerkan di Stadion Gajayana (http://mediacenter. malangkota.go.id/2015/04/berbagaiproduk-unggulan-daerah-dipamerkandi-stadion-gajayana/) accessed on June $18,2015$.

Dinas Kominfo Kota Malang. (2015) Kreatif, Kertas Tisu pun Bisa Menjadi Produk Yang Bernilai Ekonomi. (http://mediacenter. malangkota.go.id/2015/04/kreatif-kertastisu-pun-bisa-menjadi-produk-yangbernilai-ekonomi/) accessed on June 18, 2015

Dinas Koperasi UMKM Jatim. (2015). Keragaman Sektor Riil. (http:// diskopumkm.jatimprov.go.id/download. php?id=19) accessed on June 19, 2015.

Editor Indotextiles. (2012). Chinese Imports Undermine the National Industrial Competitiveness. (http://www. indotextiles.com/index.php?option $=$ com content\&task $=$ view\&id $=2218 \&$ Itemid $=56$ ) accessed on May 7, 2015.

Editor Malang Raya. (2009). Pelaku UMKM Masih Minim KesadaranakanHak Paten (The UMKM dealers are still lack of patents issue awareness). (http://malangraya. web.id/2009/08/11/pelaku-umkmmasih-minim-kesadaran-akan-hak-paten/ accessed) accessed on May 7, 2015.

Editor Malang Raya. (2009). Pelaku UMKM Masih Minim Kesadaran akan Hak Paten. (http://malangraya.web.id/2009/08/11/ pelaku-umkm-masih-minim-kesadaranakan-hak-paten/) accessed on May 7, 2015

Fauzi, Iksan. (2013). UMKM Sokong 42 Persen Perekonomian Batu. (http://surabaya. tribunnews.com/2013/12/18/umkmsokong-42-persen-perekonomian-batu) accessed on May 7, 2015.

Government of Batu City. (2013). (http:// batukota.go.id/statis-1-profil.html) accessed on June 18, 2015.

Hapsari, Pradnya Paramita, et.,al. (2014). Pengaruh Pertumbuhan Usaha Kecil
Menengah (UKM) Terhadap Pertumbuhan Ekonomi Daerah (Studi Di Pemerintah Kota Batu). Wacana: Volume 17 No 2.

Jokowi. (2015). Indonesia Paling Dtakuti (Indonesia is the Most Feared). (http:// tv.jabarprov.go.id/video/677) accessed on May 7, 2015.

Kementerian Koperasi dan Usaha Kecil Menengah. (2011). Jaringan UKM ASEAN Simpan Potensi Besar. (http://www. depkop.go.id/index.php?option $=$ com content\&view $=$ article\&id $=742$ : jari ngan-ukm-asean-simpan-potensibesar\&catid=50: bind-berita\&Itemid $=97$ ) accessed on June 18, 2015.

Malang Post. (2014). Belum Terdata, Pelatihan Dinkop Terkendala. (http://malang-post. com/kota-malang/93927-belum-terdatapelatihan-dinkop-terkendala) accessed on June 18, 2015.

Pemerintah Kabupaten Malang. (2011). Rencana Pembangunan Jangka Menengah Daerah (Rpjmd) Kabupaten Malang, 20102015. Page 11-13.

Piore and Sabel (1984) quoted in Tulis Tambunan (2012). Usaha Mikro Kecil dan Menengah di Indonesia: Isu-Isu Penting (Micro, Small, and Large Enterprises in Indonesia: Critical Issues). Jakarta: LP3ES.

Regulations by the Regent of Malang. (2011). RencanaKerjaPembangunan Daerah (Rkpd). 2012.

Secretary Directorate General of ASEAN Cooperation.(2008). ASEAN Economic Community Blueprint. Jakarta: page 5-6.

Secretary Directorate General of ASEAN Cooperation. (2010). ASEAN Selayang Pandang, 19 Edition, Jakarta: Ministry of Foreign Affairs of Indonesia.

Seputar UKM. (2014). Aset Koperasi di kab Malang Capai Lebih dari 1,5 Triliun. (http://www.seputarukm.com/asetkoperasi-di-kab-malang-capai-lebih-rp15triliun/) accessed on June 19, 2015

Tambunan, Tulus T. H. ( (2 01013$)$. MasyarakatEkonomiAsean 2015: Peluang Dan Tantangan Bagi UKM Indonesia. (http://active.kadin-indonesia.or.id/front/ policy_papers/IMG_20130618091656. pdf) Policy Paper No 15, Jakarta: Kadin Indonesia accessed on May 7, 2015. 